\title{
FEEDING FEATURES OF MULLETS
}

\section{Pavlo Shekk ${ }^{1}$ \\ Maryna Burhaz ${ }^{2}$}

DOI: https://doi.org/10.30525/978-9934-588-15-0-138

Abstract. Mullets have long been considered as one of the most important objects of sea ranching in the Black, Azov and Mediterranean basins. Representatives of a family (Mugilidae) have long been valuable objects of ranching fish farming in brackish estuaries and lagoons of the Mediterranean and Azov-Black Sea basins. Mugilidae family belongs to Mugiliforms and Acanthopterygii group consisting of ten genera and about one hundred species. There are five native species of mullets in the Black Sea: flathead grey - Mugil cephalus L., golden grey mullet - Liza aurata (Risso), leaping mullet - Lizas saliens (Risso), thicklip grey mullet - Chelon labrozus (Risso), and the thinlip mullet - Liza ramada (Risso). The first three species are of industrial importance. In the 1980s, so-iuy mullet- Liza hematocheilus (Temmink et Schlegel) was acclimated in the Black Sea and later in the Sea of Azov. Due to its high environmental plasticity, the species quickly naturalized and spread. At the same time, the abundance of native species of mullets has significantly decreased in the natural waters, as well as the number of so-iuy mullet over the last years. To ensure fingerling rearing in the Black Sea lagoons and estuaries, it is necessary to solve the problem of artificial reproduction of mullet. One of the key points of biotechnology the larval rearing - is to provide them with adequate live food. This factor is crucial. It gives juvenile growth, survival and viability. The paper is devoted to the study of feed composition and feeding preferences of mullets: flathead grey mullet, golden grey mullet and so-iuy mullet in early ontogeny. It is established that the choice of forage organisms of mullet larvae is determined by their morpho-physiological features and properties of forage

\footnotetext{
${ }^{1}$ Doctor of Agricultural Sciences, Professor,

Head of the Department of Aquatic Bioresources and Aquaculture,

Odessa State Ecological University, Ukraine

${ }^{2}$ Candidate of Biological Sciences, Associate Professor

at the Department of Aquatic Bioresources and Aquaculture,

Odessa State Ecological University, Ukraine

(C) Pavlo Shekk, Maryna Burhaz
} 
objects. The paper defines the availability of forage organisms and the selectivity of food objects by larvae of different mullet species. When switching to external feeding, the availability of the feed organism for the larva is primarily determined by its size. The larvae of Mugil cephalus need the smallest forage organisms $(50 \mu \mathrm{m})$. The larvae of Liza aurata have access to forage organisms in size of $60 \mu \mathrm{m}$, and the larvae of Liza hematocheilus - of more than $70 \mu \mathrm{m}$. Early larvae prefer trophophores of molluska and nauplii copepoda. The selectivity of the rotifers is negative at all stages of rearing. L. hematocheilus is characterized by the most nutritional flexibility. The feeding range of the larvae of this species is from 6 to 25 days and includes up to 27 food objects. The larvae of the Black Sea mullets of the flathead grey mullet and golden grey mullet are less flexible. Their diet includes from 20 to 22 food objects. In addition to animal organisms, microalgae occupy a prominent place in nutrition even in the early stages of development. After metamorphosis, the juvenile fish is reared at natural forage base and fed with artificial feeds with high-protein content (35-50\%). It follows from the features of their biology. As larvae grow, the concentration of forage organisms may decrease, and their size increases. The increase in the concentration of forage organisms does not provide an increase in the diet but causes irrational consumption of feed, thus, it makes no sense.

\section{Introduction}

Today, the world aquaculture quite successfully reproduces about 30 species of marine fish artificially, and many of them are promising objects of domestic mariculture.

Methods of collecting brood fishes, forming of brood stocks, keeping and stimulating maturation of brood fishes as well as obtaining and incubating of eggs of many species of fish are developed quite well, but the larval rearing does not always produce stable results. This is primarily due to the fact that at the early stages, most of them use exclusively living forage organisms, which have a high nutrition value and are complete in terms of amino acid composition. Thus, the selection and cultivation of adequate live food for larvae of marine fish in industrial-scale volumes is one of the most topical problems of modern mariculture.

The larvae of most marine fishes are very small, often inactive and require forage organisms which are accessible in size and speed of move- 
ment, and the feeding with those organisms can satisfy the energy needs of their organisms in ontogeny fully. The period of resorption of the yolk sac is usually short, and the period of allowable food deficiency passes quickly enough, and lack of the necessary forage can cause mass death of the larvae. When switching to active feeding, the larvae of marine fishes require live food organisms the sizes of which vary from 30 to $500 \mu \mathrm{m}$ for different larvae. The volume of food objects depends not only on the size of the larvae but also on the features of the morphological structure and structure of the mouthpart and alimentary canal, the ability of the larvae to move, etc.

The smallest (starter) feed in mariculture is usually flagellar algae, larvae of molluscs (30-100 $\mu \mathrm{m})$, rotifers $(120-200 \mu \mathrm{m})$. At the later stages of ontogeny, it is used nauplii of Artemia salina, 300 to $600 \mu \mathrm{m}$ in size, to feed the larvae.

Methods of mass cultivation of microalgae, rotifers and Artemia under artificial conditions have been developed quite well [1]. Therefore, according to the classical schemes [2], the technology of feeding with such food objects was used for larvae of righteye flounders, mullet and other marine fish after switching to external feeding.

Research has shown that the use of microalgae, artificial rotors and nauplii of Artemia as the basic starter feed do not provide a strong survival and rapid growth of marine fish larvae [3]. Therefore, along with the cultivation of live food for larvae feeding, it is used natural zooplankton which is previously filtered through special sieves. Its use often produces a much better result than the feeding of the larvae with standard forage. It is very important to change the food objects timely, corresponding to the needs of the larvae of this species at each stage of development.

Marine fishery currently pays much attention to the creation of artificial starter dry feeds balanced by the basic nutrients and appropriate for longterm storage. It would greatly simplify the technology of rearing of marine fish larvae and make it possible to avoid large losses of cultivation objects, especially at the early larval stages, due to the lack of live food required.

It is very effective to grow larvae of marine fish together with unicellular algae the presence of which in the rearing tanks contributes to the elimination of fish metabolism products, repelling of bacterial flora and maintenance of water saturation with a high level of oxygen. In addition, algae also serve as food for the small invertebrates which are fed by the larvae of marine fish. 
In determining the food objects most appropriate for specific species and stages of larval rearing, ones rely on their consumption value, the convenience of cultivation, profitability of production, etc. Moreover, the food object used must have a fairly rapid growth rate, differ in high feed efficiency, give greater production at high stocking density and be resistant to various diseases, the risk of which increases at high concentration in a limited space. Besides, cultivation of the object must be technological and have low cost price.

During the initial larval period, the concentration of food organisms should be the highest. As the larvae grow, they become more mobile and consume organisms of a relatively larger size the concentration of which may be less than of the small "starter" food organisms. The issue of the minimum concentration of food organisms for early larvae which can ensure their high survival is important. This problem has not yet been resolved.

Thus, in each particular case, to ensure a high percentage of output in the mass cultivation of larvae of marine fishes, it is necessary to establish an adequate set of food organisms, their size and concentration at different stages of ontogeny. This research is devoted to the above problem.

\section{Availability of food organisms for larvae in size}

The most important problems in the mass cultivation of marine fish at the early stages of ontogeny are as follows: the selection of food organisms adequate in size and species composition, the determination of their optimal concentration in the process of cultivation, the required amount of daily diet. Optimization of feeding conditions of the larvae allows accelerating their growth, increasing the viability and ensuring a high level of survival.

The selection of dietary components is defined by the morpho-physiological features of the larvae and the properties of the food objects. In this regard, two basic concepts are considered: the availability of a food object and feeding selectivity - the preference of the larvae of a particular food object [4].

When investigating the peculiarities of the feeding of the larvae of mullet fish, the authors pay major attention to the study of patterns of choice of species and size of food organisms, determination of their optimal concentration, diet and feeding regime of larvae. It is used a wide range of food organisms both collected in natural conditions ("wild" zooplankton) and cultivated [5]. 
Under conditions of cultivation, which are close to optimal (temperature, salinity, light, hydrochemical composition of water, etc.), larvae of soil-mullet (L. Hematocheilus) switch to active feeding on day 3-4 after hatching, flathead grey mullet (M. cephalus) and golden grey mullet (L. aurata) - on day 4.

The period of mixed feeding depends on the temperature regime of cultivation, size, type and concentration of food organisms. Under optimal conditions, it lasts from 5 to 7 days in mullets. Shortening of the mixed feeding period negatively affects the development, growth and survival of the larvae. Species, which have not filled the fish-maw and have not started eating, die. At the moment of switching to external feeding, the availability of a feed organism for larva is primarily determined by its size. The larvae of flathead grey mullet ( $M$. cephalus) need the smallest food organisms $(50 \mu \mathrm{m})$. The larvae of golden grey mullet (L. aurata) have access to feed organisms of $60 \mu \mathrm{m}$ size, and the larvae of soi-mullet (L. hematocheilus pilengas) - up to $70 \mu \mathrm{m}$ and more.

As larvae grow, the average size of food organisms consumed increases.

The dependence of the average size of food organisms of the linear size of the larvae in the early stages of ontogeny is well approximated by the logarithmic equation:

$$
Y=a \cdot \ln X+b
$$

where $Y$ - the average size of the selected feed organism, $\mu \mathrm{m}$;

$X$ - larva length, mm; $a \& b$ - coefficients.

To study species of marine fish, the parameters of equation (1) are calculated based on data on the peculiarities of their nutrition under conditions of artificial rearing (Table 1).

Table 1

\section{Parameters of the equation $Y=a \cdot \ln X+b$ connecting the length of marine fish larvae and the size of the victims selected}

\begin{tabular}{|l|c|c|c|}
\hline \multicolumn{1}{|c|}{ Fish species } & a & b & $* \mathbf{R}$ \\
\hline Soi-mullet $L$. hematocheilus & 673,5 & 639,0 & 0,982 \\
\hline Golden grey mullet $L$. aurata & 712,7 & 671,58 & 0,964 \\
\hline Flathead grey mullet $M$. cephalus & 762,4 & 680,5 & 0,972 \\
\hline
\end{tabular}

${ }^{*} \mathbf{R}-\mathrm{R}$-squared value 
The most dynamic process takes place in soi-mullet L. hematocheilus, which is able to consume large planktonic crustaceans at the age of 15-16 days. Golden grey mullet L. aurata and flathead grey mullet $M$. cephalus are the most demanding of the size of food organisms.

It would seem that the determining factor for the selection of a particular food object of larvae should be its available size, high concentration in the rearing tanks and relatively low mobility (such that energy consumption during the capture of feed objects does not exceed the amount of energy received from it) [5].

In practice, during the cultivation of marine fishes, relatively large and motile organisms, whose concentration in the breeding storages is lower than of small and low-moving objects, predominate in the feeding of early larvae.

\section{The quality characteristic of the feeding of mullet larvae}

The larvae of mullet are characterized by high nutrition plasticity. When it is used zooplankton from natural reservoirs for the feeding of larvae, the range of their diet mainly depends on the set of food organisms put into the breeding trunk, and may include more than 30 different objects (Table 2).

Planktonic crustaceans are the most significant for the nutrition of the larvae (Acartia clausi; Harpacticus littoralis; Paracalanus parvus; Calanus helgolandicus; Calanipeda aquafulcis; Podon intermedius; Cladocera; Moina micrura; Diaptomus salinus) rotifers (Rotatoria), Harpacticoida, nauplial and copepodid stages of crustaceans, mollusc larvae, polychaete and other food objects [6].

The highest food plasticity is peculiar to soi-mullet L. hematocheilus (fig. 1). Up to 27 food objects are available in the food bolus of larvae of this species at the age from 6 to 25 days. Black Sea mullet larvae have less food plasticity.

In their diet, there are from 20 (in flathead grey mullet $M$. cephalus) to 22 (in golden grey mullet $L$. aurata) food objects. In addition to animal organisms, microalgae (mainly benthic diatoms) and epiphyton, which larvae eat at the bottom and walls of storage, take a prominent place in the feeding of the early larvae of mullet.

Since the switch to active nutrition, the main food of larvae of all species of mullet (flathead grey mullet M. cephalus, golden grey mullet L. aurata 
The occurrence of food objects in the nutrition of mullet larvae Mugilidae aged from 6 to 25 days

\begin{tabular}{|c|c|c|c|c|}
\hline №№ & Forage organisms & $\begin{array}{c}\text { Flathead grey } \\
\text { mullet } \\
\text { M. cephalus }\end{array}$ & $\begin{array}{c}\text { Golden grey } \\
\text { mullet } \\
\text { L. aurata }\end{array}$ & $\begin{array}{l}\text { Soi-mullet } L \text {. } \\
\text { hematocheilus }\end{array}$ \\
\hline 1 & Acartia clausi & + & + & + \\
\hline 2 & Centropages kroyeri & + & - & - \\
\hline 3 & Harpacticus littoralis & + & + & + \\
\hline 4 & Paracalanus parvus & + & + & + \\
\hline 5 & Calanus helgolandicus & + & + & + \\
\hline 6 & Calanus euxinus & + & + & - \\
\hline 7 & Calanipeda aquafulcis & + & + & + \\
\hline 8 & Tintinnoinea (Infusoria) & + & - & + \\
\hline 9 & Penilia avirostris & - & + & + \\
\hline 10 & Pleopis polyphemoides & - & - & + \\
\hline 11 & Podon intermedius & + & + & + \\
\hline 12 & Evadne nordmani & - & - & + \\
\hline 13 & E. spinifera & + & + & + \\
\hline 14 & Oithona minuta & - & + & + \\
\hline 15 & O. simtlis & - & + & - \\
\hline 16 & Pleopis tergestina & - & - & + \\
\hline 17 & Cladocera & + & + & + \\
\hline 18 & Moina micrura & + & + & + \\
\hline 19 & Diaptomus salinus & + & + & + \\
\hline 20 & Tisbe furcata & - & + & - \\
\hline 21 & Harpacticoida & + & + & + \\
\hline 22 & Rotatoria & + & + & + \\
\hline $\begin{array}{l}23 \\
24 \\
25 \\
26 \\
27 \\
28\end{array}$ & $\begin{array}{l}\text { Larva: Bivalvia } \\
\text { Gastropoda } \\
\text { Isopoda } \\
\text { Cumacea } \\
\text { Decapoda } \\
\text { Polychaeta }\end{array}$ & $\begin{array}{l}+ \\
- \\
- \\
- \\
- \\
+\end{array}$ & $\begin{array}{l}+ \\
- \\
- \\
- \\
- \\
+\end{array}$ & $\begin{array}{l}+ \\
+ \\
+ \\
+ \\
+ \\
+\end{array}$ \\
\hline $\begin{array}{l}29 \\
30 \\
31\end{array}$ & $\begin{array}{l}\text { Nauplii: Copepoda } \\
\text { Calanoida } \\
\text { Cyclopoida }\end{array}$ & $\begin{array}{l}+ \\
+ \\
+\end{array}$ & $\begin{array}{l}+ \\
+ \\
+\end{array}$ & $\begin{array}{l}+ \\
+ \\
+\end{array}$ \\
\hline \multicolumn{2}{|c|}{ Total of food objects: } & 20 & 22 & 27 \\
\hline
\end{tabular}


Diet portion, $\%$

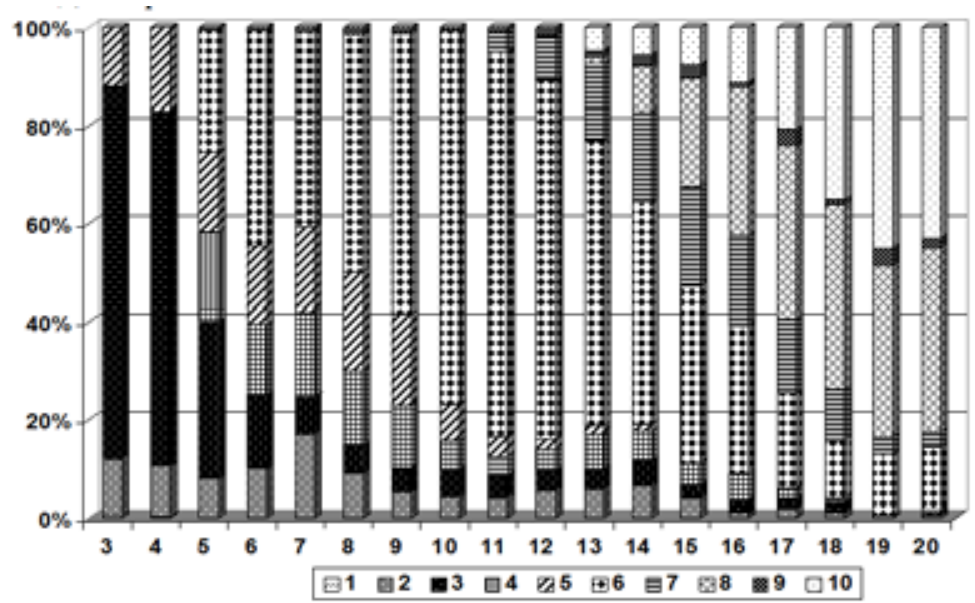

Larvae age, days

Figure 1. The spectrum of the feeding of the larvae of soi-mullet. 1 - rotifers; 2 - nauplii copepod; 3 - copepodites; 4 - infusorian; 5 - trocophores; 6 - copepods; 7 - polychaetes and decapods; 8 - artemia nauplii; 9 - other organisms; 10 - artificial feed

and soi-mullet L. hematocheilus) are nauplii copepods, rotifers and trochophores of molluscs.

In the diet of L. hematocheilus, nauplii copepods make up from 15 to $76 \%$, and in M. cephalus $-45.5-51.5 \%$ (Fig. 2), and in L. aurata-50.5-65.7 \%. Trophophores of molluscs hold second place in terms of importance (12-17; $36-37.6$ and $20.2-25.5 \%$ respectively) [8].

\section{The selectivity of larvae feeding}

The data obtained confirmed the priority of molluscs larvae and nauplii copepod in the feeding of early marine fish larvae (Fig. 3; Fig. 4). The larvae, which have begun to feed on, favor the larvae of the molluscs. Even if their concentration in the rearing tanks does not exceed $0.1-0.2 \%$, their selectivity of soi-mullet $L$. hematocheilus during the first 10 days is from 0.54 to 0.99 , and flathead grey mullet $M$. cephalus has from 0.50 to 0.97 up to 20-days age. 
Diet portion, \%

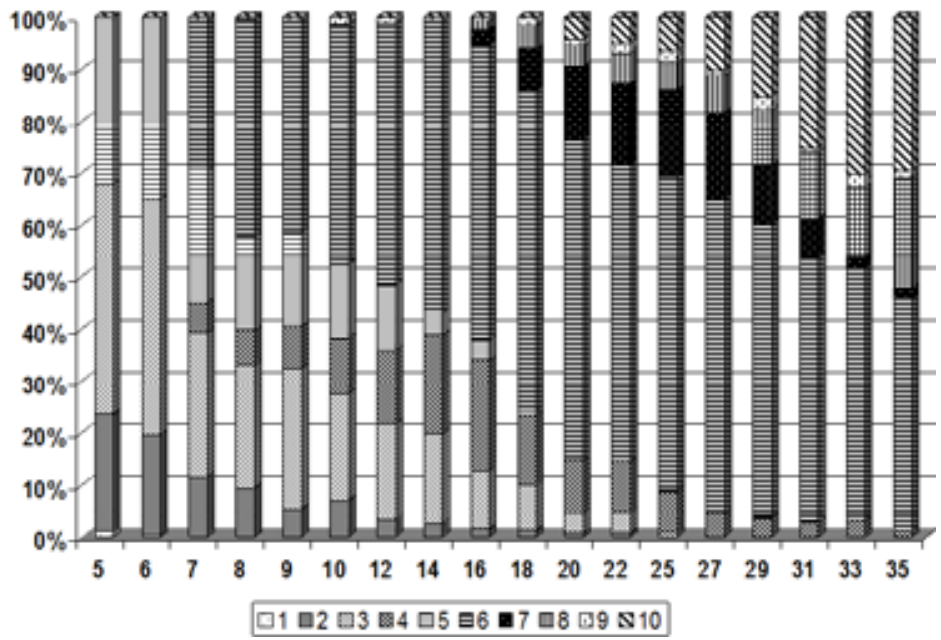

Larvae age, days

Figure 2. The spectrum of the feeding of the larvae of flathead grey mullet 1 - rotifers; 2 - nauplii copepod; 3 - copepodites; 4 -infusorian; 5 - trocophores; 6 - copepods; 7 - polychaetes and decapods; 8 - artemia nauplii; 9 - other organisms; 10 - artificial feed.

Nauplii copepods hold second place in terms of selectivity, even if their concentration in the rearing tanks is $0.2-0.4$ species $\cdot \mathrm{cm}^{-3}$ and lower. Moreover, the concentration of, for example, rotifers can reach 5-8 species $\cdot \mathrm{cm}^{-3}$ and more.

The selectivity index of nauplii copepod by larvae of $L$. hematocheilus varies from 0.18 to 0.26 during the first 5 days since the start of feeding. Black Sea turbot has from 4 to 7 days $-0.34-0.45$, and from 8 to 10 days $0.18-0.29$. At the later stages, nauplii copepods, obviously, are of secondary importance in the feeding of the larvae and the indicator of their selectivity does not exceed $0.1-0.02$.

Due to a small size and low mobility, the rotifer, as forage, is available even for the weakened dwarfed larvae.

However, the low nutrition value of this object does not repay the larvae's consumption on food production fully. It is perhaps a reason that they 
Diet portion, $\%$

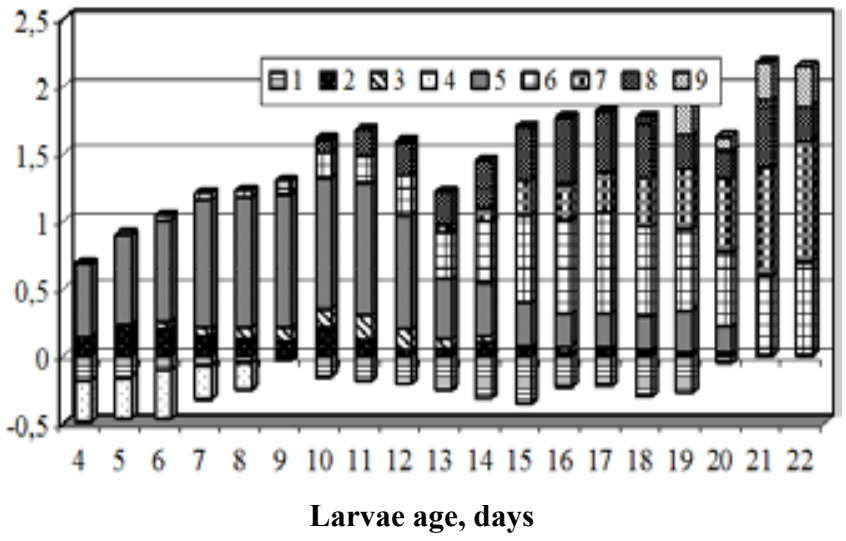

Figure 3. The selectivity of the feeding of soi-mullet larvae. 1 - rotifers; 2 - nauplii copepod; 3 - copepodites; 4 - infusorian; 5 - trocophores; 6 - copepods; 7 - artemia nauplii; 8 - polychaetes and decapods; 9 - artificial feed

prefer energy-efficient, albeit more mobile and larger objects, such as nauplii copepods or mollusk larvae.

During the rearing of larvae of marine fishes, it was found that the survival of the larvae, whose diet consisted exclusively of rotifers in early ontogeny, was lower in 5-7 times in soi-mullet and in 3-5 times lower in golden grey mullet than those receiving nauplii copepods and trophophores of molluscs (Figure 5).

At 8-days age, the selectivity of adult copepods by the larvae increases. The maximum indicator of their electivity $0.60-0.61$ is marked on the $9-10^{\text {th }}$ day, that is, at the beginning of metamorphosis.

In the next 10 days, the electivity of these organisms remains high enough ( $E-0.44-0.47)$.

The significance of polychaete larvae in feeding of the larvae of L. hematocheilus has been increasing since 10-11 days. Their electivity is 0.45-0.46 and remains consistently high until the beginning of the juvenileperiod. At the age of 9-10 days, the larvae can be fed with nauplii artemia and artificial feed. Consumption of naupelia artemia is limited only by the size of the larvae, and election increases as the larvae grow. 
Selectivity

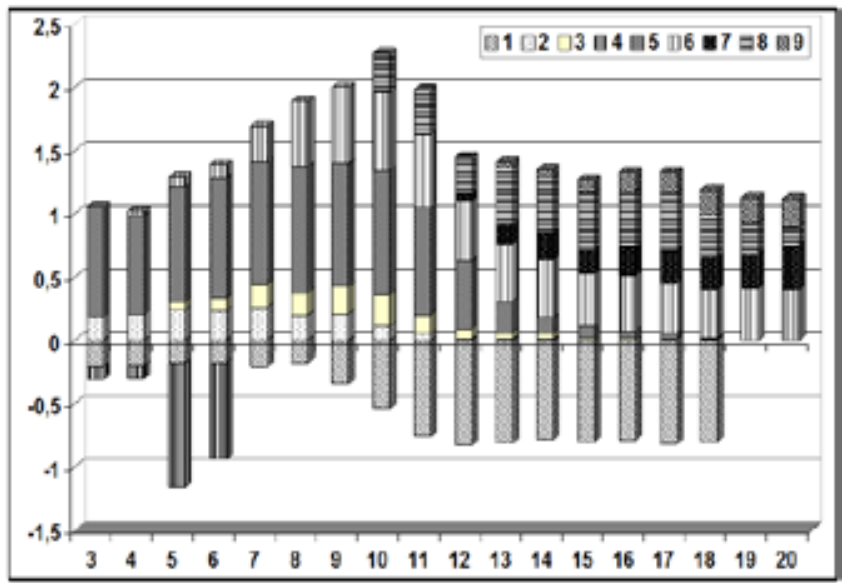

Larvae age, days

Figure 4. The selectivity of the feeding of the larvae of flathead grey mullet M. cephalus.

1 - rotifers; 2 - nauplii copepod; 3 - copepodites; 4 - infusorian; 5 - trocophores; 6 - copepods; 7 - artemia nauplii; 8 - polychaetes and decapods; 9 - artificial feed

At first, the larvae reluctantly eat artificial feed preferring living organisms. By the age of 15-17 days, their portion in the diet is $5-10 \%$, and by the end of metamorphosis $-60 \%$ and more.

A similar pattern of nutritional benefits is also observed among the larvae of other marine fish.

When feeding mullet larvae at the early ontogeny, one of the most important problems is the selection of forage organisms adequate in the size and species composition, the determination of their optimal concentration in the rearing tanks, diet volume.

Optimization of the conditions for larvae feeding allows accelerating their growth, increasing the vitality and ensuring a high survival level. The choice of nutrients in the diet is determined by the morphophysiological features of the larvae and the properties of the food objects. In this context, two basic concepts are considered: the availability of a food object and elective feeding or the preference of the larvae to certain forage organisms. 


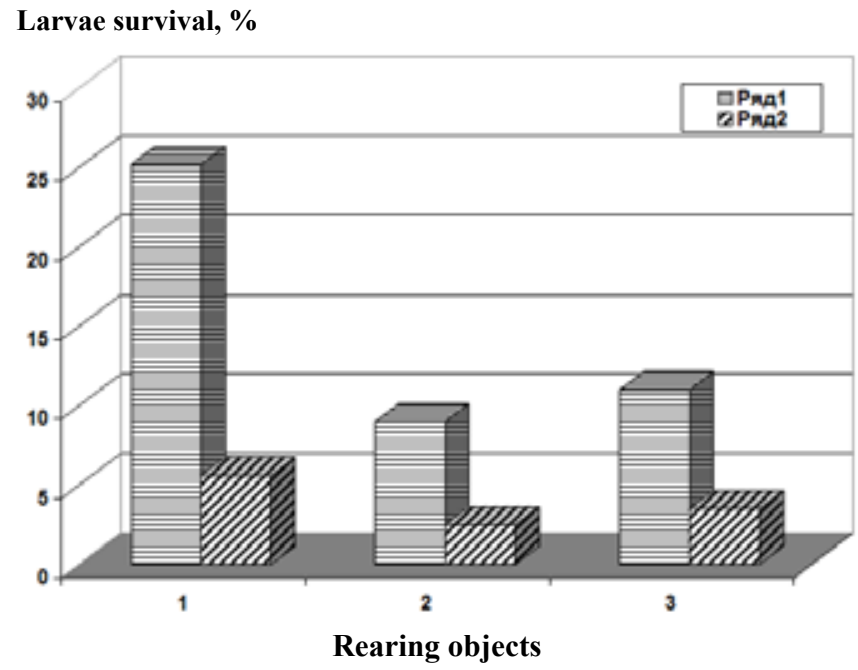

\section{Figure 5. Survival of mullet larvae during feeding with nauplii copepods and trophophores of molluses (1) and artificially cultivated rotifers (2) in the early xontogeny}

The fodder organisms that act as the larvae's food are divided into: favorite, changeable and forced food, or, in the terms of real value: the main, minor and occasional.

The favorite means the food that the larvae prefer to any other. Changeable is a food which the larvae ignore when their favorite one is available but when it isn't they prefer changeable. Forced food is preferred when the main and changeable one is not available.

When developing the methods of mass cultivation, the emphasis is upon the choice of species and size of forage organisms, the determination of their optimal concentration, diet volume and feeding pattern of the larvae.

In the process of switching to external feeding, the availability of forage organisms is determined, first of all, by their size. The smallest food objects are essential for the larvae of flathead grey mullets $M$. cephalus (50 $\mu$ m averagely).

Organisms of $60 \mu \mathrm{m}$ in size are available for golden grey mullets L. aurata, and organisms to $70 \mu \mathrm{m}$ or more in size are available for soi-mullet larvae L. hematocheilus. As larvae grow, the average size of food or- 
ganisms consumed increased. This process most dynamically takes place among soi-mullet $L$. hematocheilus and flathead grey mullet $M$. cephalus, which can feed on organisms in size of $800 \mu \mathrm{m}$ or more on the $10-11^{\text {th }}$ day (Figure 6).

Average size of forage organisms, $\mathbf{m m}$

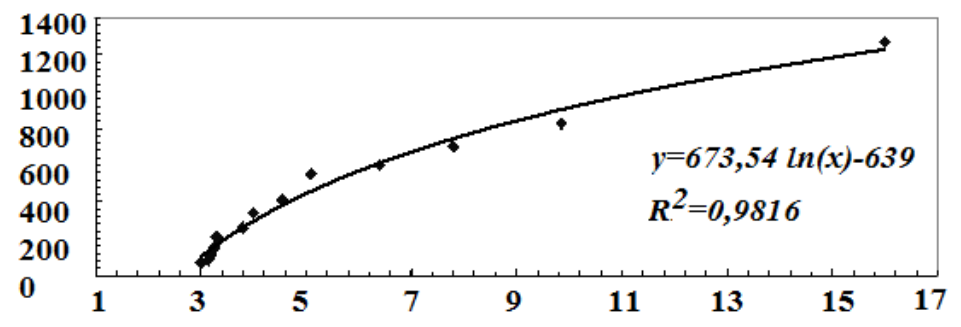

Larvae length, $\mathbf{m m}$

Figure 6. Dependence of average size of forage organisms on the linear size of soi-mullet larvae L. hematocheilus

The larvae of flathead grey mullet $M$. cephalus are able to consume forage organisms of size $500-600 \mu \mathrm{m}$ on the $20-25$ th day and golden grey mullet $L$. aurata - at the 25-30 day (Figure 7; Figure 8).

It is interesting that the larvae of all mullet species can feed on large planktonic organisms at about the same size [7].

Average size of forage organisms, $\mathbf{m m}$

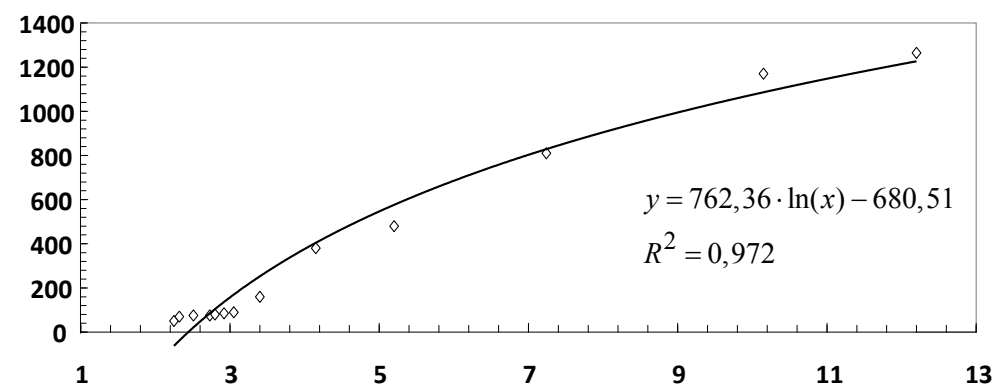

Figure 7. Dependence of average size of forage organisms on the linear size of the larvae of flathead grey mullets M. Cephalus 


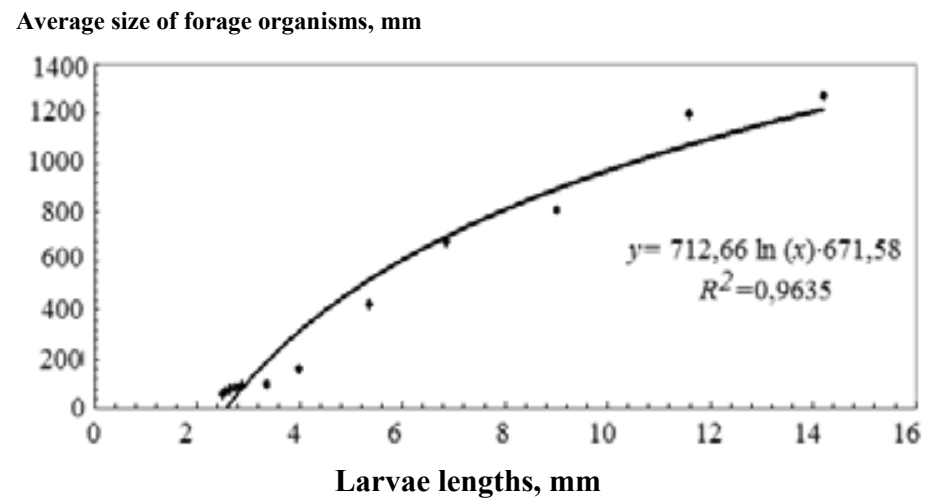

Figure 8. Dependence of average size of forage organisms on the linear size of the larvae of golden grey mullets

Despite the fact that the growth rate significantly varies among different species, there is a differentiation in time over the size of available food objects.

The dependence of the average size of the larvae and their victims is well approximated by the logarithmic equation at the early stages of ontogeny:

$$
Y=a \cdot \ln L+b,
$$

where $Y$ - the average size of the selected forage organism, $\mu \mathrm{m}$;

$L$ - larval length, mm;

$a \& b$ - coefficients

The parameters of equation (2) for different species of marine fish were calculated on the basis of the actual data obtained by the authors (Table 3 ).

Table 3

Parameters of the equation $Y=a \cdot \ln L+b$, which connects the length of the larvae size of the organisms selected by them.

\begin{tabular}{|l|c|c|c|}
\hline \multicolumn{1}{|c|}{ Species } & a & b & r \\
\hline Soi-mullet $L$. hematocheilus & 673,5 & 639,0 & 0,982 \\
\hline Goldern grey mullet L. aurata & 712,7 & 671,58 & 0,964 \\
\hline Flathead grey mullet M. cephalus & 762,4 & 680,5 & 0,972 \\
\hline
\end{tabular}


In switching to external feeding, the availability of forage organisms. Soi-mullet $L$. hematocheilus has the most dynamic process, and it is able to consume large planktonic crustaceans at the age of 15-16 days. Golden grey mullet $L$. aurata and flathead grey mullet $M$. cephalus are the most capricious to the size of the food objects of the larva.

\section{The dependence of the diet volume of larvae on the density of forage organisms}

In studying the patterns of feeding of larvae of marine fish during their mass rearing, the analysis of the dependence of volume of their diet on the density of the population of forage organisms takes an important place. At the same time, it is necessary to deal with both homogeneous and mixed populations.

In the first case, a common population of even-aged larvae close in size and their victims - planktonic organisms - is formed in the rearing tank. Otherwise, in the basin it is formed larvae population, which is complex, heterogeneous in size and age, small larvae consuming planktonic organisms become first-order predators, and second-order predators are large larvae which are capable of consuming small dwarfed larvae besides planktonic organisms.

The concentration of planktonic organisms $5 \mathrm{spec} \cdot \cdot \mathrm{cm}^{-3}$ creates favorable conditions for feeding for an ordinary population of early larvae of soi-mullet $L$. hematocheilus (6-7 days) at low stocking density (30 spec. $\cdot \mathrm{cm}^{-3}$ ). Under such conditions, the diet of the larvae reaches a maximum and further increase in the density of forage organisms does not lead to its growth, and therefore it does not make sense since it is not accompanied by rational feed consumption. At high density of larvae stocking $\left(100 \mathrm{spec} \cdot \mathrm{cm}^{-3}\right)$, the optimal feeding conditions are ensured by the concentration of forage organisms $6-7 \mathrm{spec} \cdot \cdot \mathrm{cm}^{-3}$.

For the population of larvae at the age of 10 days, which were fed with nauplii artemia and copepods (stocking density $80 \mathrm{spec} \cdot \cdot^{\cdot} \mathrm{cm}^{-3}$ ), the concentration of forage organisms 4 spec. $\cdot \mathrm{cm}^{-3}$ was optimal. Similar data were obtained for flathead grey mullet. The concentration of forage organisms $7 \mathrm{spec} \cdot{ }^{\cdot} \mathrm{cm}^{-3}$ provided the optimal feeding conditions (maximum diet) for larvae at the age of 8 days under the stocking density for growing $60 \mathrm{spec} \cdot \mathrm{cm}^{-3}$, and $50 \mathrm{spec} \cdot \cdot \mathrm{cm}^{-3}-4-5 \mathrm{spec} \cdot \cdot \mathrm{cm}^{-3}$ was the stocking density for the juvenile larvae (15-17 days). 
The dependence of the diet volume $(R)$ on the concentration of forage organisms $(C)$ for the 10-days larva of soi-mullet (stocking density 80 spec. $\cdot \mathrm{cm}^{-3}$, feed - nauplii artemia $-80 \%$ and planktonic crustaceans $20 \%$ ) renders the equation (3):

$$
R=0,080 \cdot \ln C+0,29
$$

Under such conditions, the lowest level of cannibalism on the part of large larvae was observed in the rearing basins.

The diet volume of 6-7 days larvae of soi-mullet (stocking density is 30 spec. $\cdot \mathrm{cm}^{-3}$ ) were fed with "wild" zooplankton (copepods $-72-87 \%$, rotifers $-10-22 \%$, mollusks trochophore $-2-6 \%$ ) is approximated by the equation (4):

$$
R=0,0563 \cdot \ln C+0,147
$$

Under the stocking density of larvae $100 \mathrm{spec} \cdot \bullet^{-\mathrm{cm}^{-3}}$ and other equal conditions, the equation has the following form (5)

$$
R=0,0517 \cdot \ln C+0,135
$$

Cannibalism is observed among complex populations of large larvae which are heterogeneous in size. Predominantly it concerns the larvae of soi-mullet, flathead grey mullet and golden grey mullet, which were fed with artemia, copepods and other large forage organisms (size $-1000-1500 \mu \mathrm{m}$ and larger). The proportion of small larvae in the diet of large individuals, under the concentration of planktonic forage organisms 4-5 spec. $\cdot \mathrm{cm}^{-3}$ did not exceed 5-7\%.

Intensification of the concentration of forage organisms in the rearing tank up to 6-7 spec. $\cdot \mathrm{cm}^{-3}$, reduction of the density of stocking of larvae and their sorting by size reduces or completely stops cannibalism. By reducing the concentration of forage organisms in the tank up to $2-3 \mathrm{spec} \cdot \cdot^{\cdot} \mathrm{cm}^{-3}$, the part of small larvae in the feeding of juvenile individuals increases up to $7-15 \%$.

The mullet larvae feed only during daylight hours. In the context of natural light and photoperiod, 5-8 days larvae of soi-mullet feed on dawn (from 4 a.m.) and continue to hunt throughout photoperiod (until 10-11 p.m.). They don't have expressed feeding rhythm, which is determined only by the time of digestion. Upon constant maintenance of optimal concentration of forage organisms in the rearing tanks, 9-10 days larvae have a three-peak daily rhythm of feeding. When forage organisms (zooplankton) are put into the tanks in the morning $(8-10 \mathrm{a} . \mathrm{m}$.) and daytime ( $4-6 \mathrm{p} . \mathrm{m}$.) time, there are two peaks of the feeding intensity coinciding with foddering. 
Larvae do not feed at night. In the context of 24-hour artificial daylight, they continue to feed at night but less intensively than in the daytime. Under such light conditions, the natural daily rhythm gets broken after 10-15 days. There are from 4 to 8 less expressed peaks with an increase in the feeding intensity in 1.5-2 times that affects the growth rate of the larvae.

Usually the transition of the larvae of marine fish to external feeding occurs simultaneously with the filling of the fish-maw. Sometimes, because of different circumstances, some of the larvae that fill the fish-maw don't start to feed. Starvation can last for up to 4-5 days, if larvae begin to consume forage organisms during this period they survive. Although, they significantly lag behind in growth and development, otherwise, their death is observed on the $7-10^{\text {th }}$ day.

Larvae, which have switched to external feeding in time, may stop feeding in extreme conditions (rapid decrease or increase in temperature, oxygen deficiency, lack of adequate feed in the required concentration, etc.). When the conditions of cultivation are optimized, they start eating again without pronounced negative effects.

The turnover period of starvation for early (up to 10-15 days) larvae is from 5 to 7 days. In this case, up to $90-100 \%$ of soi-mullet larvae and $60-80 \%$ of the larvae of flathead grey mullet, golden grey mullet and Black Sea turbot can start feeding again when optimizing of growth environment and the availability of a sufficiently high $\left(5-7 \mathrm{spec} \cdot \cdot \mathrm{cm}^{-3}\right)$ concentration of small forage organisms (mollusks trochophore and rotifers) in the rearing tanks. The larvae of Pleuronectes flesus luscus can survive aLonger period of reversible starvation. At the optimum temperature they can live without food up to 10-14 days and up to 14-17 days in terms of the temperature decrease (up to $12-14^{\circ} \mathrm{C}$ ) during the cultivation.

They start to feed again in the context of the optimization of the conditions and the availability of a sufficiently high concentration of the relevant forage organisms up to $85-95 \%$ of the larvae without visible consequences.

Soi-mullet larvae can consume artificial feeds since the $10-12^{\text {th }}$ day, flathead grey mullet - since the $28-30^{\text {th }}$ day, and golden grey mullet - since the $37-40^{\text {th }}$ day. At first, larvae take artificial feeds reluctantly preferring living organisms. But after 5-7 days, artificial feeds compose 5-10\% of the diet, and $60 \%$ or more - by the end of the metamorphosis. The larvae and young marine fish require feed with a high content of animal protein. This 
follows from the features of its biology. The basis of the diet of young fish in natural conditions is animal food (up to $80 \%$ ). Therefore, under rearing in the artificial conditions, granular feed with high protein content are preferred. In an experiment with early soi-mullet, they were fed with standard artificial feed. The maximum monthly average gain of weight $8.5-8.0 \mathrm{~g}$ $\left(0.283-0.267 \mathrm{~g} \cdot\right.$ day $\left.^{-1}\right)$ was obtained using feeds PГМ-6M and KP-C containing $46-45 \%$ of protein, $8-11 \%$ of fat. The feed ratio was $2.5-3.3$. The use K-III-I and ПК-IIO-I with a protein content of $24-26 \%$ and fat content of $2.5 \%$ slowed their growth. The average monthly increase in fry did not exceed $3 \mathrm{~g}\left(0,101 \mathrm{~g} \cdot\right.$ day $\left.^{-1}\right)$, and the feed coefficient was 7.5-8.8. РГМ-8М and Ст-4aA3 (44-54\% of protein and $9-15 \%$ of fat) provided an average monthly increase amounting 7.0-7.2 g (0.233-0,240 g - day $\left.{ }^{1}\right)$ with a feed factor of 3.0-3.2. It is obvious, the last two types of feed guarantee the same good results as РГМ-6M and KP-C, but it is inexpedient to use them in the industrial cultivation of soi-mullet due to its high cost.

\section{Conclusions}

1. Based on the obtained nutrition characteristics of mullet larvae, the authors calculate the parameters of the equation $Y=a \cdot \ln X+b$ connecting the linear sizes of the larvae and the sizes of their victims. After switching to external feeding, the smallest forage organisms are needed by the larvae of flathead grey mullet $M$. cephalus $(45-50 \mu \mathrm{m})$. The larvae of golden grey mullet $L$. aurata and soi-mullet $L$. hematocheilus have access to feed organisms of size $60-70 \mu \mathrm{m}$ or more.

2. Early larvae prefer trophophores of mollusks and nauplii copepods. The selectivity of the rotary wheel at all stages of cultivation is negative.

3. As larvae grow, the concentration of forage organisms in the rearing tanks decreases, and their size increases.

4. The diet of even-aged larvae depends on the density of their stocking for the cultivation and concentration of forage organisms. It is established the concentrations of forage organisms which ensure the maximum diet and growth rate depending on the density of stocking of the larvae for cultivation. It is shown that an increase in the concentration of forage organisms does not lead to an increase in the diet, and therefore it does not make sense since it is accompanied by unreasonable consumption of feed. 
5. The scheme of larvae breeding for all mullet species remains the same regardless of the reproduction object. It is changed bio-standards that are specific and vary depending on the biological and physiological characteristics of the reproductive object (larvae size, time of transition to active feeding, degree of mouth opening, etc.).

6. Technology of feeding mullet larvae (regardless of species) includes the following main stages: at the beginning of the third (fourth) day after hatching, it is put live feeds into the rearing systems - nauplii copepods, trochophores of molluscs and rotifers. The primary concentration of forage organisms should be $7-8 \mathrm{spec} \cdot \cdot \mathrm{cm}^{-3}$. On the fourth or fifth day, about $80 \%$ of the larvae switch to active feeding. They are fast growing, active and can consume larger food objects. At the age of 7-9 days, the larvae eat adult cyclops, kalaniped, acartia and other crustaceans. On the $8-15^{\text {th }}$ day of the cultivation, it is put nauplii artemia in the tank which gradually occupy a leading place in the feeding of the larvae. After the metamorphosis, the larvae begin to feed on artificial fodder like "Еквізо", Ст-4 Аз, РГМ-6 М etc. in parallel with live food. After the metamorphosis, the larvae are put up in fry ponds. Fry is reared on a natural forage base and fed with artificial feeds with high protein content (35-50\%). This follows from the features of their biology.

7. Golden grey mullet is characterized by longer larval development. The transition to external feeding and filling of fish-maw with air occurs on the $5-6^{\text {th }}$ day, and metamorphosis begins on the $23-25^{\text {th }}$ day and ends on the $40-45^{\text {th }}$ day. Accordingly, the mode of their feeding differs from that the above one in terms of the introduction of live and artificial feed.

8. When switching to external feeding, larvae of soi-mullet and golden grey mullet can feed on larger objects than the larvae of flathead grey mullet. At the age 7-8 days, they consume organisms up to 750 microns in size, and feed nauplii artemia and adult copepods at 10-11 days of age. From 20day age, they easily react to starter artificial feeds the proportion of which is gradually increasing in the diet.

\section{References:}

1. Shekk P.V., Kulikova N.I. Marikultura ryb i perspektivy ee razvitiya $\mathrm{v}$ Chernomorskom bassejne: Monografiya. Kyiv: KNT, 2005. 308 s.

2. Movchan Yu. V. Ryby Ukrainy. Kyiv, 2011. $420 \mathrm{~s}$.

3. Andriyashev A.P. Ryby morej SSSR [opredeliteli po faune. 53]. M.-L., 1954. 
4. Shekk P.V., Kryukova M.I. Ocenka kormovoj bazy i perspektiva ispolzovaniya Shabolatskogo limana dlya pastbishnoj marikultury. Visnik zaporizkogo nacionalnogo universitetu. Zaporizhzhya, 2010. S. 126-135.

5. Shekk P.V., Burgaz M.I. Harakteirista pitaniya kefalevih ryb v Shabolatskom limane. Scientific Journal «ScienceRise: Biological Science» № 4(7), 2017. S. 21-26.

6. Burgaz M.I. Zooplankton Shabolatskogo limanu. XII Mezhdunarodnoj ihtiologicheskoj nauchno-prakticheskoj konferencii «Sovremennye problemy teoreticheskoj i prakticheskoj ihtiologii» 26-28 sentyabrya 2019, Dnepr, s. 46-49.

7. Shekk P.V., Burgaz M.I. Osobennosti pitaniya i pishevye vzaimootnosheniya kefalevih ryb v Shabolatskom limane, kak faktor opredelyayushij strategiyu ih pastbishnogo vyrashivaniya. Materiali H mizhnarodnoyi ihtiologichnoyi naukovopraktichnoyi konferenciyi «Suchasni problemi teoretichnoyi i praktichnoyi ihtiologiyi». Kyiv, 2017. S. 382-384.

8. Shekk P.V., Burgaz M.I. Ekologo-biologichna harakteristika kefali pilengasa Lizahaematocheilus (TemmincketSchlegel, 1845) v limanah pivnichno-zahidnogo Prichornomor'ya XI mizhnarodna ihtiologichna naukovo-praktichna konferenciya (Lviv, 18-20 veresnya 2018 r.) «Suchasni problemi teoretichnoyi i praktichnoyi ihtiologiyi». S. 179-183. 